Int.J. Hum. Soc. Dev. Res.

ISSN (P):2521-1439; ISSN (E):2523-4331

Volume 4, Number 1, 2020. 74-82

DOI:10.30546/2523-4331.2020.4.1.74

\title{
DID THE 2008 GLOBAL FINANCIAL CRISIS AFFECT THE BANKING CREDITS? A CASE OF REGIONS OF TURKEY
}

\author{
Fatma Sibel UĞURLU \\ Istanbul Aydın University, Turkey
}

(C) The Author(s) 2020

\section{ABSTRACT}

In 2008 the world faced a global crisis which is started from the US; thus it is named as a "US Great Recession. In this paper, we investigate whether the 2008 financial crisis has an effect on Turkish banking credits in regional case. For this aim we use Nonspecialized Loans Deposit which is collected from The Banks Association of Turkey as an annual data. The period of the paper is 2004-2014. The selected regions are 11 NUTS1 regions; thus we have panel data with 121 observations. We use two dummy variable; first dummy values are 1 for 2008 and 0 for other years, a second dummy variable is 1 for 2008 and successor years; 0 for other years. The first dummy shows if the crisis affects only one year, the second dummy shows if the crisis affects crisis year and successor years.

(C)2020.All rights reserved

ARTICLE HISTORY

Received: 5/01/2020

Accepted: 02/04/2020

Published online: 27/04/2020

\section{KEYWORDS}

Financial Crisis, Stock Market, Panel Data, Turkish banking credits, global crisis 


\section{Introduction}

In 2007 the decline of US housing prices and the collapse of the mortgage market caused a global financial crisis (Aksoy and Ugurlu,2015). It is named as a subprime mortgage crisis, and the reason for the crisis is an unusually large fraction of subprime mortgages originated in 2006 and 2007 (Yuliya and Hemert, 2008). The subprime mortgage crisis continues and affects the 2008 economic situation of the USA. Because the USA has the most significant financial markets in the world, it affects all countries. After the first steps of the crisis in August 2007, a number of European banks announced their heavy investments in the U.S. mortgage-backed securities thus; it was clear to say that the European economy affected by the crisis (Edey, 2009).

After the USA economy had shocked, it spread to the world. At first, European economies were affected from the crisis because of ties with the USA economy, then the concern was raised of contagion to other markets; in the end, crises spread from one country to another. We have seen the crisis effects on the Turkish economy too. The effects were in all sectors, and one of them is the banking sector. One of the aims of the banking system is to provide credit to the economy. Many sectors such as manufacturing, agricultural, commercial and service use credits to sustain their work or make an investment. That is why credits are very important for the economies, and there is a relationship between credits and economic growth.

The aim of this paper is to investigate the effect of the 2008 crisis on the banking credits of Turkey. The contribution of this paper to the literature is twofold. The first contribution is to see the effect of the crisis on non-specialized loans, and the second one we investigate its regional dimension. We use annual data of non-specialized loans of the Turkish banking sector among the regions of Turkey for the 2004-2014 period. The contribution of this paper is to the finance literature is to determine the crisis effect on banking credits of regions of Turkey. The remained sections of the paper are as follows: Section 1 summarizes the literature review, section 3 applies an empirical application, and summarizes the main findings. In the fourth section, the paper is summarized. 


\section{Literature review}

In Turkey, new national banks were established between 1923-1932 (Gultekin and Karakas 2009), between 1933 to 1938 state banks then in 1950s Turkish Industrial Development Bank (TSKB) were founded (Ozturk, Karakas and Hisarciklilar, 2010). The banking sector has been continuing to grow with many private banks. In 1980 a structural adjustment program was launched, and deposit and of loan rate were liberated ( Mercan et al., 2003). In 1999 Banking Regulation and Supervision of Agency (BDDK) was established and The Savings Deposit Insurance Fund (TMSF) regulations come into force (Boyacioglu,2003). After this brief information of the Turkish banking sector in the literature review section, we focus on crisis and credit relationship papers. Tong \& Wei (2008) investigate whether the subprime crisis spills over to the real economy. They found that a tightened liquidity squeeze is economically more important than reduced consumer spending. Barro (2001), Cerra \& Saxena (2005), and Becker \& Mauro (2006) are other studies find financial shocks have GDP costs, which are discussed in Tong \& Wei (2008).

Bast1 (2009) discusses the effect of the crisis and finds that Turkey has a negative but limited impact from the crisis. Also, the Turkish banking sector's solvency and profitability level were very high during the crisis. Onder and Ozyildirim (2011) investigate political ties between bank credits and growth for Turkey, and they state that the banking sector constitutes a large part of the financial system of Turkey before 2008 .

Ksantini \& Boujelbène (2014) aims to find the impact of financial crises on GDP growth and investment for 25 countries for the period of 1998 to 2009. The authors estimate a panel data model, and then the results show that the financial crisis affects growth and investment.

Aksoy \& Ugurlu (2015) investigate the effect of the 2007-2008 financial crisis on Turkish firms by using monthly data from 2004-2009, and they find that the global financial crisis had a significant but weak effect on Turkish firms.

Besides these macro-level structural modeling approaches, some scholars employed more innovative data sources to explain the changing of trends in the volume of bank credits. For instance, Zeybek \& Uğurlu (2015) use internet search trends to forecast the amount of newly opened consumer loans. Yüksel 
(2017) focuses on credit risk using a non-performing loans ratio and finds that the industrial production index is the most important factor on non-performing investments in Turkey.

In this context of the previous research, our empirical application opens a different window to the literature. Generally, the previous researches investigate the relationship using time series or panel data for the countries. In this paper, a regional perspective is taken into consideration.

\section{Empirical application}

In this section, Non-specialized Loans Deposit of 11 NUTS1 regions is used. Although Turkey has 12 NUTS1 (Nomenclature of Territorial Units for Statistics ) regions, we use 11 regions by omitting TR 1 region, which is consisted of only one city İstanbul. The source of the data is The Banks Association of Turkey website (www.tbb.org.tr) from the data page Information by Geographical Regions and Provinces. The Banks Association of Turkey divides loans into two groups; specialized loans and non-specialized loans. Specialized loans are classified into two groups that are real estate loans, vocational loans, maritime loans, tourism loans, and other loans.

\section{Data Set}

The data set consists of 11 regions and 11 years. In this study, the data set has both cross-section and time series; it means that the data set is a panel data set. It includes 121 observations using 11 cross-sectional units and 11-time series units. The regions are 11 NUTS 1 region. Although NUTS 1 (Nomenclature of Territorial Units for Statistics ) has 12 regions, we use 11 regions because one of the region -TR 1 İstanbul- is a city, whereas other regions are territorial units. Table 1 shows the NUTS 1 units' code and name.

Table 1: Classification of Statistical Regional Units

\begin{tabular}{|l|l|}
\hline Code & Region \\
\hline TR6 & Mediterranean \\
\hline TR5 & Western Anatolia \\
\hline TR8 & Western Blacksea \\
\hline TR2 & Western Marmara \\
\hline
\end{tabular}




\begin{tabular}{|l|l|}
\hline TR9 & Eastern Blacksea \\
\hline TR4 & Eastern Marmara \\
\hline TR3 & Aegean \\
\hline TRC & South Eastern Anatolia \\
\hline TRA & North Eastern Anatolia \\
\hline TR7 & Middle Anatolia \\
\hline TRB & Middle Eastern Anatolia \\
\hline
\end{tabular}

Figure 1 shows the NSL data graph by year. We can see that the significant increase start after 2009. If the graph is drawn by region, the crises effect on regions will see easily.

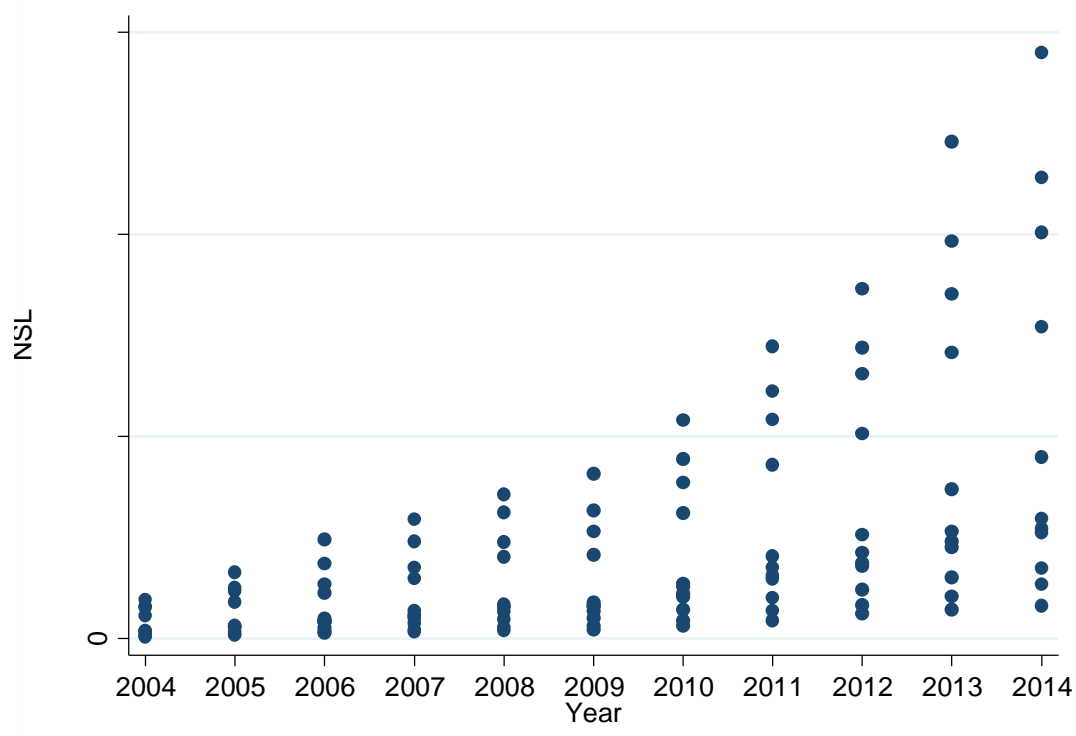

Figure 1. Non-specialized Loans Deposit by Year

Figure 2 shows NSL by regions. All regions have increasing trends and also have two increasing trends that can be seen in nearly all regions. The majority of the regions decreased in 2009 .

In Aegean, Eastern Marmara and Mediterranean region, 2009 values of NSL are lower than in 2008. It is the first indicator of the effect of the 2008 crises. In South Eastern Anatolia from the graph, we can see that the values of the 2008 
and 2009 are very close and from the data set, we can see that the values are 8.0e+06 and 8.1e+06 respectively. This shows that South-Eastern Anatolia region is affected by the crisis too. If the data of the regions are investigated, it can be seen that there is a decrease or low proportional increase in the 2009 year. Then we expect that; 2009 year has the impact of the crisis of 2008 on the values of NSL.
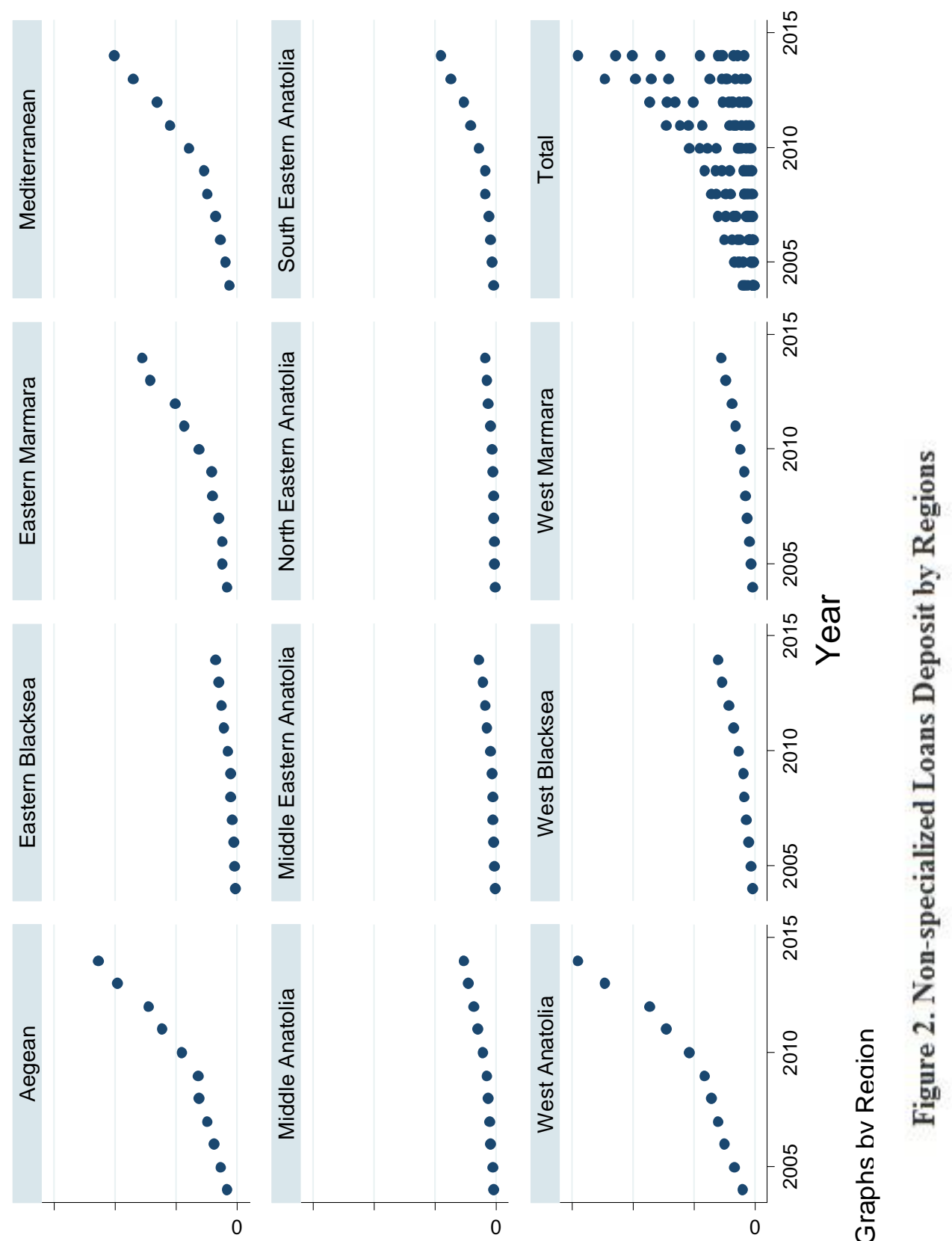


\section{Model}

In the model side, we use a panel data model technique that is a fixed effect model. In the panel data model, three kinds of models can be estimated. Pooled OLS, fixed effect model and random effect model (Ugurlu, 2010). In this study we use all cities then we use a fixed effect model because we choose all individuals than our sample cannot be random. If we interested in comparing means between levels of a variable we should use the fixed effect but if we compare among levels of variables we should use random effects (Gurka et al., 2012)

I test if there is a significant break in 2008 or 2009. Therefore we define two dummy variables. We estimate two autoregressive models with crisis break dummy variables.

First one is named as a D2008 which is 1 for 20080 for others; the second one is D2009 which is 1 for 2009 and 0 for others. The models estimated are:

$\mathrm{NSL}_{i t}=\alpha_{\mathrm{i}}+\beta_{\mathrm{i}} \mathrm{NSL}_{\mathrm{it}-1}+\beta_{2} \mathrm{D} 2008+\varepsilon_{\mathrm{it}}$

$N S L_{i t}=\alpha_{i}+\beta_{i} N S L_{i t-1}+\beta_{2} D 2009+\varepsilon_{i t}$

(2)

Table 2: Model 1 Results

\begin{tabular}{|l|l|l|l|l|}
\hline Variable & Coefficient & Std. Err. & t & P \\
\hline NSL(-1) & .4784544 & .0743663 & 6.43 & 0.000 \\
\hline $\mathrm{d} 2008$ & -3455308 & 5960268 & -0.58 & 0.563 \\
\hline Constant & $1.20 \mathrm{e}+07$ & 2491335 & 4.81 & 0.000 \\
\hline \multicolumn{5}{|l|}{} \\
\hline R-sq within & 0.2918 & $\mathrm{~F}(2,107)$ & 22.04 & 0.0000 \\
\hline R-sq between & 0.9310 & & & \\
\hline R-sq overall & 0.4735 & & & \\
\hline
\end{tabular}

Table 2 shows the results of the first model. The model is statistically significant and has enough explanatory ratios. Model is statistically significant in $1 \%$ level. However, the dummy variable of 2008 is not significant; thus we can say that the 2008 year has no significant effect. 
Table 3: Model 2 Results

\begin{tabular}{|l|l|l|l|l|}
\hline Variable & Coefficient & Std. Err. & t & P \\
\hline NLS(-1) & .4794485 & .073868 & 6.49 & 0.000 \\
\hline D2008 & -4036113 & 5920325 & -0.68 & 0.497 \\
\hline Constant & $1.20 \mathrm{e}+07$ & 2466229 & 4.87 & 0.000 \\
\hline \multicolumn{5}{|l|}{} \\
\hline R-sq within & 0.2926 & $\mathrm{~F}(2,107)$ & 22.13 & 0.0000 \\
\hline R-sq between & 0.9310 & & & \\
\hline R-sq overall & 0.4743 & & & \\
\hline
\end{tabular}

Table 3 shows the results of the model which has the 2009 year dummy. In this model, the dummy variable is not significant therefore 2009 has no significant effect on loans. Model is statistically significant in $1 \%$ level and has a enough explanatory ratio.

\section{Conclusion}

Crisis and its effect on economy is widely investigated issue. There are many crisis in history of the world economy. Last world crisis occurred in 2008 which started in USA because of mortgage. There is no definite time about the crises, 2007 or 2008 but it spreads to world.

In this paper, we investigated the relationship between the 2008 crisis and the Turkish banking sector non-specialized loans deposit. To test these relationships we estimated fixed effect panel data model. The results show that the two dummy variables are not significant; thus the crisis has no effect on loans.

\section{Disclosure statement}

No potential conflict of interest was reported by the author.

Contact Information.

Email address:ugurlu@gmail.com 


\section{References and notes:}

Aksoy, E. E. and Ugurlu, E. (2015) "How did the 2007-2008 Financial Crisis Influence Turkish Firms", Journal of Economics and Political Economy, 2(4), pp. 494-506.

Barro, R. J. (2001) "Economic Growth in East Asia Before and After the Financial Crisis", NBER Working Papers, 8330.

Bast1, E. (2009) "2008 Global Financial Crisis And The Turkish Financial System” Ç.Ü. Sosyal Bilimler Enstitüsü Dergisi, 18(2), 89-103

Becker, T. and P. Mauro. (2006) "Output Drops and the Shocks that Matter", IMF Working Papers, 06/172, 1-43.

Boyacıoğlu, M. A. (2003) “1980 Sonrası Türk Bankacılık Sektöründeki Gelişmeler, Krizlerin Sektör Üzerindeki Etkileri ve İyileştirici Öneriler" Selçuk Üniversitesi Sosyal Bilimler Enstitüsü Dergisi (9),523-538

Cerra, V. and Saxena S. C. (2005) "Eurosclerosis or Financial Collapse: Why Did Swedish Incomes Fall Behind?", IMF Working Papers, 05/29.

Demyanyk, Y. S. and Van Hemert, O. (2008) "Understanding the Subprime Mortgage Crisis" Available at SSRN: https://ssrn.com/abstract=1020396

Edey, M. (2009) "The Global Financial Crisis and Its Effects", Economic Papers, 28 (3), 186195.

Gultekin-Karakas D. (2009) Global Integration of Turkish Finance Capital: State, Capital and Banking Reform in Turkey, Vdm Verlag Dr. Müller Aktiengesellschaft \& Co. Kg

Ksantini M., and Boujelbène Y. (2014) "Impact of Financial Crises on Growth and Investment:An Analysis of Panel Data", Journal of International and Global Economic Studies, 7(1), 32-57

Mercan, M., Reisman, A., Yolalan, R., and Emel, A. (2003)" The effect of scale and mode of ownership on the financial performance of the Turkish banking sector: results of a DEA-based analysis". Socio-Economic Planning Sciences, 37(3), 185-202. doi: 10.1016/s0038-0121(02)00045-9

Onder, Z., and Ozyildirim, S. (2011) "Political Connection, Bank Credits and Growth: Evidence from Turkey", The World Economy, 34(6), 1042-1065. doi: 10.1111/j.14679701.2011.01342.x

Öztürk, H., Gultekin-Karakas D. and Hisarciklilar, M (2010). "The Role Of Development Banking In Promoting Industrialization In Turkey". Region Et Developpement, 32, 153-178. Retrieved from https://ideas.repec.org/a/tou/journl/v32y2010p153178.html

Tong, H.and Wei, S. H. (2008) " Real Effects of the Subprime Mortgage Crisis: Is it a Demand or a Finance Shock?", IMF Working Paper WP/08/186

Ugurlu, E. (2012) "Real Exchange Rate And Economic Growth: Turkey", Manas University Social Sciences Journal, 2009, 191-212

Ugurlu, E. (2010) "Growth and Openness Relationship in the EU-15: Panel Data Analysis", Ekonomika, 89(2), 44-54.

Vaidotas P. and Jočienė A. (2014) "Subprime Mortgage Crisis In The United States In 2007 2008: Causes And Consequences (Part I)", Ekonomika, 93(4),85-118

Yüksel, S. (2017) "Determinants of the Credit Risk in Developing Countries After Economic Crisis: A Case of Turkish Banking Sector in Global Financial Crisis and Its Ramifications on Capital Markets, Springer International Publishing 401-415. doi: 10.1007/978-3-319-47021-4_28

Zeybek, Ö. and Uğurlu, E., (2015) "Nowcasting credit demand in Turkey with Google Trends Data”, Journal of Applied Economic Sciences, 10(2), 293-300. 